\title{
Streptomyces thermogriseus, a new species of the genus Streptomyces from soil, lake and hot-spring
}

\author{
Li-Hua Xu, Yong-Qian Tiang, Yun-Feng Zhang, Li-Xing Zhao \\ and Cheng-Lin Jiang
}

Author for correspondence: Cheng-Lin Jiang. Tel: +868715033790. Fax $:+868715173878$.

Yunnan Institute of Microbiology, Yunnan University, Kunming, Yunnan 650091, China

\author{
Many thermophilic actinomycetes were isolated from samples collected from a \\ hot-spring, lake and soil in Yunnan, China. Chemical and molecular \\ classification of four selected strains of thermophilic Streptomyces with an \\ upper limited growth temperature of $65-68{ }^{\circ} \mathrm{C}$ and autolytic characteristics \\ was carried out. A new species, Streptomyces thermogriseus sp. nov. is \\ described. The type strain is $\mathrm{Y}^{-14046^{\top}}$ ( = CCTCC AA97014').
}

Keywords: Streptomyces thermogriseus sp. nov., thermophile

\section{INTRODUCTION}

Thermophilic actinomycetes are useful as producing organisms of antibiotics, enzymes and other bioactive metabolites because of their rapid growth rate and rapid autolysis of mycelium $(11,12,17)$. They are useful for studying the evolution and adaptation mechanism of organisms to extreme environments. They are also an important resource for development of industrial products $(2,11,12,15,16,17)$.

We have isolated many thermophilic streptomycetes from hot-springs, lakes and soils in the whole of Yunnan. We studied the morphological, cultural, physiological and biochemical characteristics, gel electrophoretic patterns of isoenzymes, cell composition and sequences of 16S rRNA genes of four selected isolates of Streptomyces. A new species with the name Streptomyces thermogriseus sp. nov. was described by comparing relative species of the genus.

\section{METHODS}

Actinomycete strains. The soil or sediment samples were collected from forests, hot-springs and lakes in Yunnan. Thermophilic streptomycetes were isolated using ISP 2, ISP 3 , ISP 5, colloidal chitin agar (4), AV agar (13) and HV agar (3) media after the pretreatment of air-dried samples at $120^{\circ} \mathrm{C}$ for $1 \mathrm{~h}$, and incubated at 55 or $60^{\circ} \mathrm{C}$ for $3-7 \mathrm{~d}$. After primary purification, the isolates were incubated on ISP 2 agar medium. Strain Y-4027 was isolated from soil samples in Kunming, Y-5114 from Chenghai Lake, Y-14046 ${ }^{\mathrm{T}}$ and Y-14082 from a hot-spring in Eryuan, Yunnan, China. These four strains, which have autolytic characteristics, were selected for the classification studies. Some reference strains for comparison were obtained from ATCC, IFO, NRRL, CCRC and CCCCM.
Morphology. The media used for micromorphological studies were yeast extract-malt extract agar (ISP 2) and oatmeal agar (ISP 3) (14), and the incubation time was $5-10$ d at $55^{\circ} \mathrm{C}$. Morphological observations of spores were made with a light microscope and a model EPMA-8705 electron microscope.

Cultural, physiological and biochemical tests. The media and procedures used for determining the cultural and physiological characteristics, and carbon and nitrogen source utilization of the strains were those described by Shirling \& Gottlieb (14) and Locci (8). Colour determinations were made by comparing the cultures with colour chips from the ISCC-NBS color charts standard samples no. 2106 (6).

Extraction of isoenzymes. Each strain was grown on yeast extract-malt extract broth with shaking at $55^{\circ} \mathrm{C}$ to lateexponential growth phase. The cells were harvested by centrifugation at $4000 \mathrm{~g}$ for $10 \mathrm{~min}$ and were washed with distilled water. The cells were stored at $-20{ }^{\circ} \mathrm{C}$ until use. The cells were disrupted with $0.1 \mathrm{~mm}$ glass beads in a mortar for $20 \mathrm{~min}$ in $0 \cdot 1 \mathrm{M}$ Tris/ $\mathrm{HCl}$ buffer $(\mathrm{pH} \mathrm{7.5)}$. Homogenates were centrifuged at $15000 \mathrm{~g}$ for $20 \mathrm{~min}$, and supernatants containing isoenzymes were decanted out. The isoenzyme extracts were stored at $-20^{\circ} \mathrm{C}$.

Polyacrylamide gels were prepared by the method of Maurer (9). A $3.0 \%(\mathrm{w} / \mathrm{v})(\mathrm{pH} 6.7)$ large-pore upper gel and a $7.5 \%$ (pH 8.9) small-pore separation gel were prepared. The electrode buffer contained $0.005 \mathrm{M}$ Tris, $0.038 \mathrm{M}$ glycine (pH 8.3). The gel electrophoresis was performed at 10-20 $\mathrm{mA}$ per gel slab for 5-6 h.

Staining procedures. The six isoenzymes tested were alcohol dehydrogenase (ADH; EC 1.1.1.1), malate dehydrogenase (MDH; EC 1.1.1.37), glutamate dehydrogenase $(\mathrm{GDH}$; EC 1.4.1.4), glucose-6-phosphate dehydrogenase (G6PDH; EC 1.1.1.49), esterase (EST; EC 3.1.1.1) and superoxide dismutase (SOD; EC 1.15.1.1). The staining procedures used for these enzymes were described by Weeden \& Wendel (18) and Wendel \& Weeden (19). After 
staining, the gels were dried with a model 583 gel dryer. The relative mobilities $\left(R_{m}\right)$ of the enzyme bands were calculated as the ratio between the mobility distance of the enzymes and the mobility distance of the tracking dye from the origin. A sample was tested at least twice for each enzyme.

Chemical composition of the cell wall. Cell walls were purified and analysed using the method of Lechevalier \& Lechevalier (7). The procedures of Becker et al. (1) and Lechevalier \& Lechevalier (7) were used for analysis of whole-cell chemical composition.

16S rRNA gene sequence determination and analysis. Genomic DNAs were extracted using the DNA extraction procedures $(5,20)$ and were used for PCR amplification of $16 \mathrm{~S}$ rRNA genes. The $16 \mathrm{~S}$ rRNA gene was amplified by $\mathrm{PCR}$ in a reaction mixture containing $1 \times \mathrm{PCR}$ buffer (SinoAmerican Biotechnology), primer A 5-24r (5'-CCG TCG ACG AGC TCA GAG TTT GAT CCT GGC TCA G-3') and primer B 1525-1506r (5'-CCC GGG TAC CAA GCT TAA GGA GGT GAT CCA GCC GCA-3'). The final volume of the PCR mixture was adjusted to $50 \mu \mathrm{l}$ by adding distilled $\mathrm{H}_{2} \mathrm{O}$ and the reaction mixture was overlaid with $100 \mu \mathrm{l}$ sterile mineral oil. Thermal cycling was performed with a model 1109 DNA Amplifier made in China. The samples were subjected to an initial denaturing step consisting of $3 \mathrm{~min}$ at $95^{\circ} \mathrm{C}$, after which $2 \mathrm{U}$ Taq polymerase was added to each sample at $90^{\circ} \mathrm{C}$. The thermal profile used was 35 cycles consisting of $1 \mathrm{~min}$ of primer annealing at $56^{\circ} \mathrm{C}, 2$ min extension at $72^{\circ} \mathrm{C}$ and 1 min denaturation at $95^{\circ} \mathrm{C}$. A final extension step consisting of $10 \mathrm{~min}$ at $72^{\circ} \mathrm{C}$ was included. Amplified DNA was detected by agarose gel electrophoresis and visualized by UV fluorescence after ethidium bromide staining.

The PCR product was purified and concentrated using agarose gel electrophoresis. The purified PCR products were directly sequenced. The sequencing reactions were performed with a DyeDeoxy Terminator Cycle Sequencing Kit using AmpliTaq FS (Applied Biosystems). The sequencing primers used were A, B and C 1115-1100r (5'-AGG GTT GCG CTC GTT G-3'). The sequencing reaction mixtures were electrophoresed on a $6 \%$ polyacrylamide sequencing gel using a model 377 Prism Automatic DNA sequencer (Applied Biosystems).

The 16S rRNA gene sequences were manually aligned with the sequences of members of the order Actinomycetales using the ae 2 editor (10). Genetic distances were calculated by using the PAUA 3.11. Phylogenetic dendrograms were reconstructed using treeing algorithms contained in the PHYLIP package. Bootstrap analyses were used to evaluate the tree topologies of the neighbour-joining data by performing 100 or 500 resamplings.

\section{RESULTS AND DISCUSSION}

\section{Morphological observation}

Morphological observation of the 3-7 d-old culture of strains $\mathrm{Y}-4027, \mathrm{Y}-5114, \mathrm{Y}-14046^{\mathrm{T}}$ and $\mathrm{Y}-14082$ grown on yeast extract-malt extract agar revealed an abundant aerial mycelium $(0.5-1.5 \mu \mathrm{m}$ in diameter $)$ which could arise from substrate mycelium. Spore chains with many spores were Rectiflexibiles, Retinaculiaperti or occasionally Spirales. The spores were spherical or subspherical, and non-motile. The spores of strain Y4027 were spherical or subspherical ( $1 \mu \mathrm{m}$ in diameter $)$,

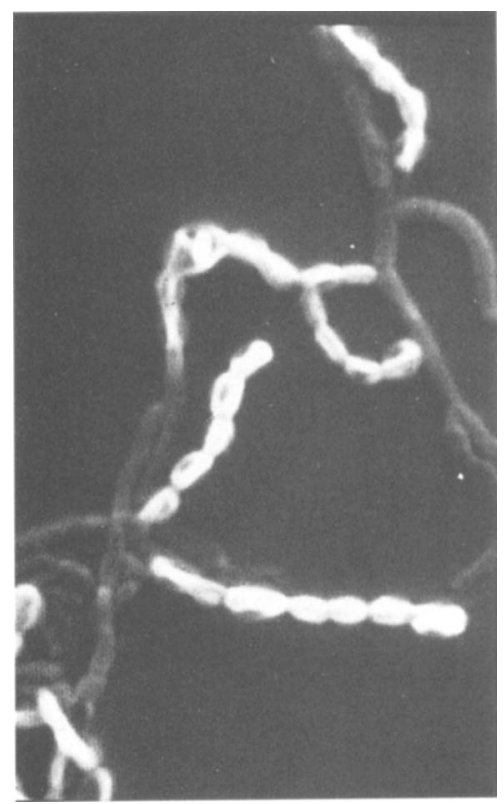

Fig. 1. Morphological characteristics of Streptomyces thermogriseus.

those of strain $\mathrm{Y}-5114$ were short rods $(1 \times 1.5-2.0 \mu \mathrm{m})$ and those of strains $\mathrm{Y}-14046^{\mathrm{T}}$ and $\mathrm{Y}-14082$ were spherical or subspherical $(0.7 \mu \mathrm{m}$ in diameter $)$. The spore surface was smooth (Fig. 1).

\section{Cultural characteristics}

Cultural characteristics of the four strains are shown in Table 1. Strain Y-4027 produced sparse aerial mycelium while aerial mycelium of $\mathrm{Y}-5114, \mathrm{Y}-14046^{\mathrm{T}}$ and Y-14082 was abundant and white, grey or yellow, becoming black after autolysis. The substrate mycelium was yellowish brown. Diffusible pigments and melanin were not produced.

\section{Physiological and biochemical characteristics}

The physiological and biochemical characteristics of the four strains are shown in Table 2. The characteristics of the four strains were almost the same except for growth in $7 \%(\mathrm{w} / \mathrm{v}) \mathrm{NaCl}$ and production of lecithinase. The upper limits of growth temperature were $65-68{ }^{\circ} \mathrm{C}$.

\section{Electrophoretic pattern of isoenzymes}

The electrophoretic patterns of six isoenzymes of strains Y-4207, Y-5114, Y-14046 ${ }^{\mathrm{T}}, \mathrm{Y}-14082$ and six typical strains are shown in Fig. 2. The patterns of G6PD, SOD and EST were the same for the four strains. The electrophoretic pattern of the MDH of Y5114 had two extra bands at $R_{m} 0 \cdot 2$ and $0 \cdot 6$. The ADH pattern of Y-4027 and Y-14082 showed one extra band at $R_{m} 0 \cdot 2$ and that of GDH of Y-5114 and Y-14046 
Table 1. Cultural characteristics of four strains

From Inter-Society Color Council-National Bureau of Standards color-name charts.

\begin{tabular}{|c|c|c|c|c|c|}
\hline \multirow[t]{2}{*}{ Medium } & \multirow[t]{2}{*}{ Mycelium* } & \multicolumn{4}{|c|}{ Strain: } \\
\hline & & $Y-4027$ & $Y-5114$ & $Y-14046^{T}$ & Y-14082 \\
\hline \multirow[t]{3}{*}{ Czapek agar } & AM & - & White & Grey & Light grey-brown \\
\hline & SM & Yellowish grey & Light brown-grey & Grey & Light grey \\
\hline & $\mathrm{SP}$ & - & - & - & - \\
\hline \multirow{3}{*}{$\begin{array}{l}\text { Glycerol asparagine } \\
\text { agar }\end{array}$} & $\mathrm{AM}$ & - & Grey & - & White \\
\hline & SM & Pale yellow & Yellowish grey & Yellowish grey & Grey-yellow \\
\hline & SP & - & - & - & - \\
\hline \multirow{3}{*}{$\begin{array}{l}\text { Inorganic salts-starch } \\
\text { agar }\end{array}$} & $\mathrm{AM}$ & - & - & - & - \\
\hline & SM & Yellowish grey & Yellowish grey & Yellowish grey & Yellowish grey \\
\hline & SP & - & - & - & - \\
\hline \multirow[t]{3}{*}{ Oatmeal agar } & $\mathrm{AM}$ & - & Yellowish white & - & Grey yellow \\
\hline & SM & Yellowish white & Yellowish white & Yellowish grey & Yellowish grey \\
\hline & SP & - & - & - & - \\
\hline \multirow{3}{*}{$\begin{array}{l}\text { Yeast extract-malt } \\
\text { extract agar }\end{array}$} & AM & - & Olive-black & Yellowish grey & Light grey \\
\hline & SM & Light olive-brown & Olive-brown & Light olive-brown & Light olive-brown \\
\hline & SP & - & - & - & - \\
\hline \multirow[t]{3}{*}{ Potato extract agar } & $\mathrm{AM}$ & - & Deep grey & Grey-yellow & - \\
\hline & SM & Grey-yellow & Grey-yellow & Grey-yellow & Pale yellow \\
\hline & SP & - & - & - & - \\
\hline
\end{tabular}

*AM, Aerial mycelium; SM, substrate mycelium; SP, soluble pigments.

Table 2. Physiological and biochemical properties of four strains

+ , Positive, utilized; -, negative, not utilized.

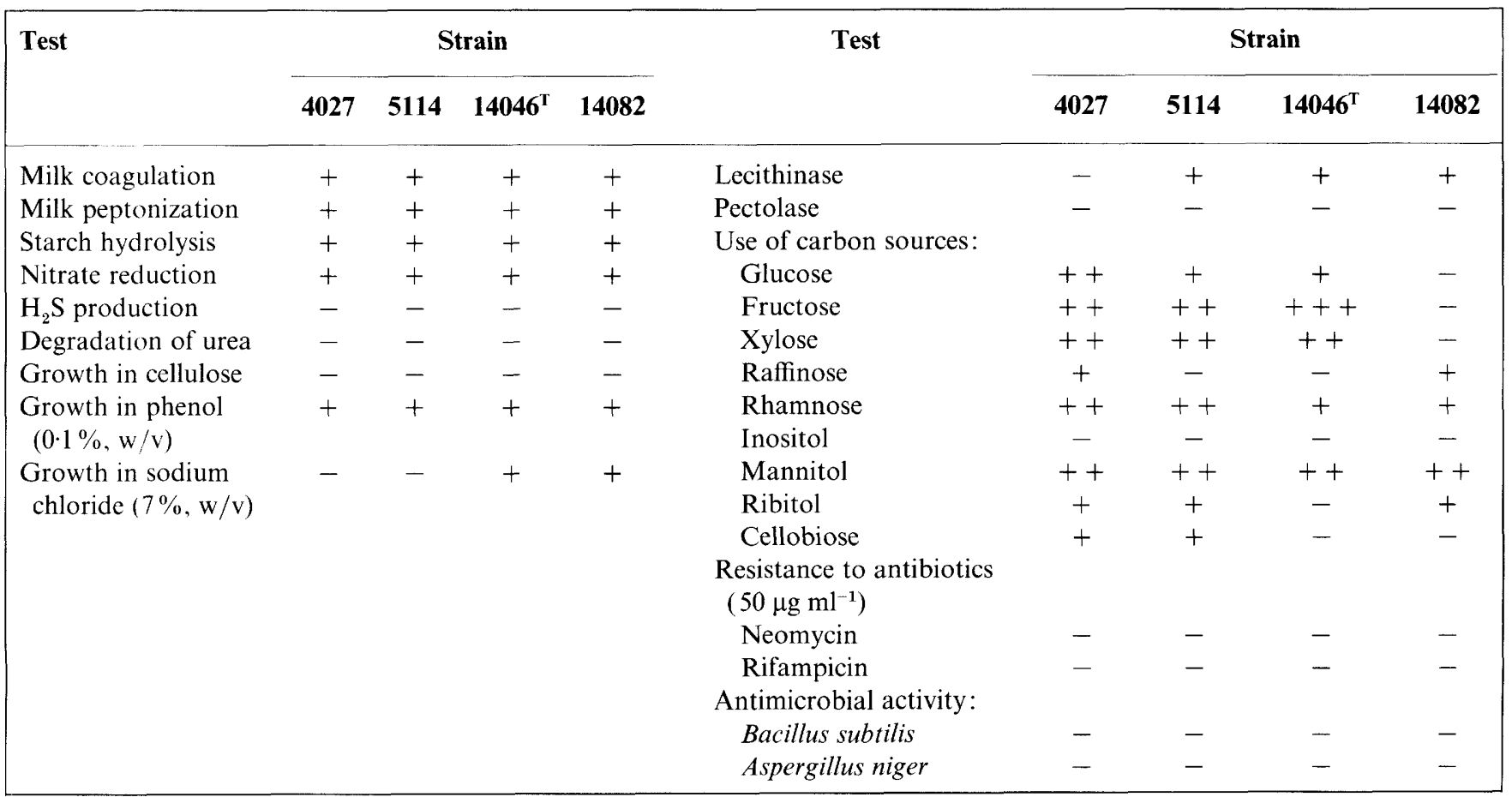




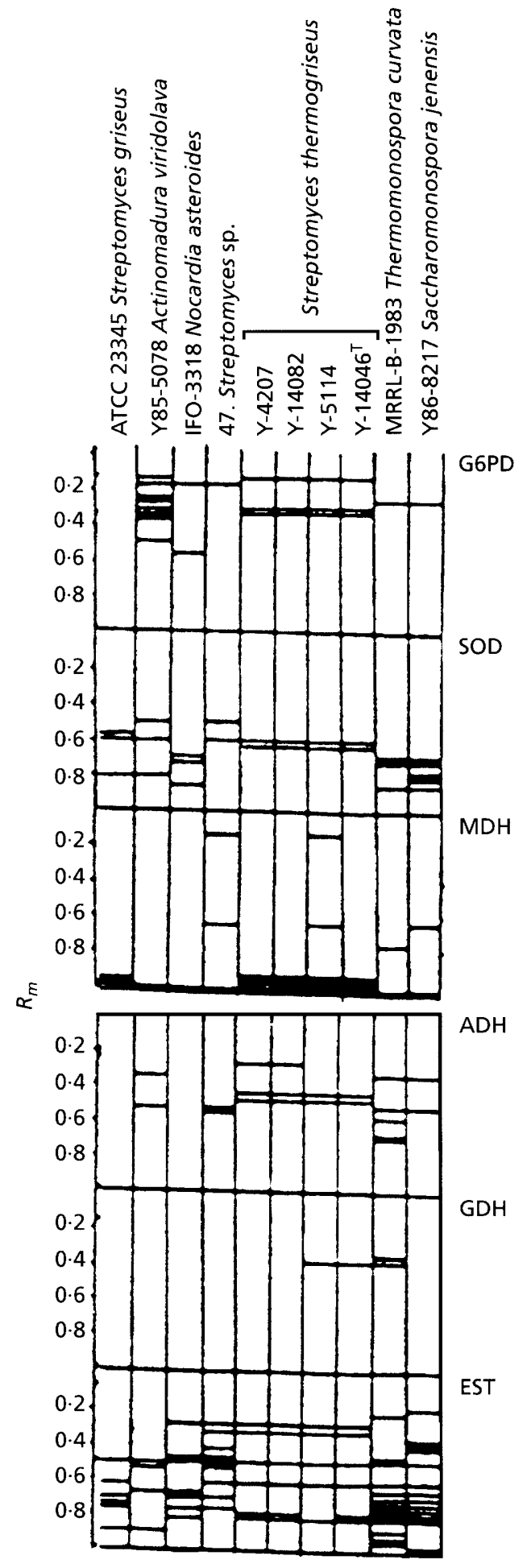

Fig. 2. Diagrammatic representation of electrophoretic patterns of six isoenzymes of 10 strains of actinomycetes.

had one extra band at $R_{m} 0 \cdot 3$. The number of patterns of the six isoenzymes of the four strains was greater than those of Streptomyces griseus and different from those of other genera.

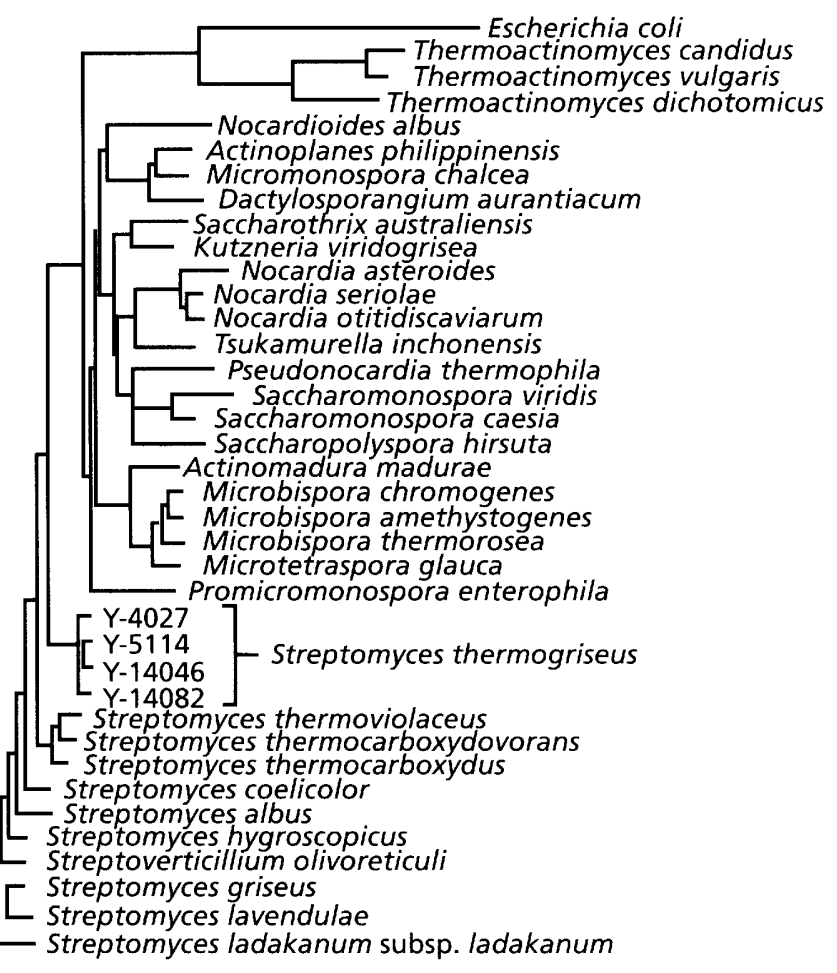

Fig. 3. Phylogenetic tree based on $16 \mathrm{~S}$ rRNA gene sequences showing relationships among four strains of Streptomyces thermogriseus, related species of the same genus and other taxa.

\section{Chemotype of cell wall}

The cell wall of all the four strains contained Ldiaminopimelic acid and glycine. The whole-cell hydrolysates contained galactose.

\section{S rRNA gene sequences}

The almost complete 16S rRNA gene sequences of strains Y-4027, Y-5114, Y-14046 ${ }^{\mathrm{T}}$ and Y-14082 which we determined contained 1467, 1476, 1423 and 1383 nucleotides, respectively. A result of the phylogenetic analysis of the four strains and some typical strains of the genus Streptomyces and other genera is shown in Fig. 3.

The strict consensus parsimony trees (not shown) and the neighbour-joining phylogram (Fig. 3) constructed using the Kimura- 2 model based on the entire sequence data of $16 \mathrm{~S}$ rRNA genes were extremely similar. The four strains of autolytic thermophilic Streptomyces were related with $99.5 \%$ similarity of $16 \mathrm{~S}$ rRNA gene sequences.

Based on the morphological characteristics, cell wall chemotype and sequences of 16S rRNA genes, strains $\mathrm{Y}-4027, \mathrm{Y}-14082, \mathrm{Y}-5114$ and $\mathrm{Y}-14046^{\mathrm{T}}$ should be included in the genus Streptomyces. The four strains should be identified as a single species because of the 
high similarity value $(99.5 \%)$ of their 16 S rRNA gene sequences, despite their morphological, cultural, physiological and biochemical characteristics, and the different electrophoretic patterns of some of the six isoenzymes tested. However, similarity values of $16 \mathrm{~S}$ rRNA gene sequences among the four strains and Streptomvces hygroscopicus (8), S. griseus and other members of the genus Streptomyces with thermophilic and autolytic characteristics were less than $95 \%$. Thus, we propose that the four strains should be a new species, Streptomyces thermogriseus sp. nov.

\section{Description of Streptomyces thermogriseus sp. nov.}

Streptomvces thermogriseus (ther.mo.gri.seus. M.L. adj. therme heat; adj. griseus grey; M.L. thermogriseus heat, grey).

Brown or yellow vegetative hyphae. Grey or white aerial hyphae, becoming black after autolysis. The spores are spherical, subspherical or short rods. Spore surface is smooth. Neither diffusible pigment nor melanin is produced. Milk is coagulated and peptonized. Lecithinase may or may not be produced. Hydrolyses starch. Nitrate reduction. $\mathrm{No}_{2} \mathrm{~S}$ production. No growth on cellulose. Growth in $0.1 \%$ phenol. Growth or no growth in $7 \% \mathrm{NaCl}$. No degradation of urea. Utilizes rhamnose and mannitol. Utilizes or does not utilize glucose, fructose, xylose, raffinose, ribitol and cellobiose. Does not utilize inositol. No resistance to neomycin and rifampicin. No antimicrobial activities are detected. Growth at 65-68 ${ }^{\circ} \mathrm{C}$. The cell wall contains $\mathrm{L}$-diaminopimelic acid and glycine. The whole-cell hydrolysate contains galactose. Strain Y-4027 (= CCTCC AA97012) was isolated from soil samples of Kunming, Y-5114 (= CCTCC AA97013) was from Chenghai Lake, and $\mathrm{Y}-14046^{\mathrm{T}} \quad\left(=\right.$ CCTCC $\quad$ AA97014 $\left.{ }^{\mathrm{T}}\right)$ and $\mathrm{Y}-14082$ (= CCTCC AA97015) were from a hot-spring in Eryuan, Yunnan, China. The type strain is $\mathrm{Y}-14046^{\mathrm{T}}$.

\section{ACKNOWLEDGEMENTS}

The authors gratefully thank Dr Zheng-Fu Lu for his help in the preparation of the phylogenetic trees. The work was supported by the National Natural Science Foundation of China and International Cooperation Foundation of Yunnan

\section{REFERENCES}

1. Becker, B., Gordon, R. E., Lechevalier, H. A. \& Lechevalier, M. P. (1964). Rapid differentiation between Nocardia and Streptomvees by paper chromatography of whole cell hydrolysates. Appl Microbiol 12, 421-423.

2. Cross, T. (1968). Thermophilic actinomycetes. J Appl Bacteriol 31, 36-53.

3. Hayakawa, M. (1990). Selective isolation methods and distribution of soil actinomycetes. Actinomycetologica 4, $103-112$.
4. Hsu, S. C. \& Lockwood, J. L. (1975). Powder chitin agar as a selective medium for enumeration of actinomycetes in water and soil. Appl Microbiol 29, 422-426.

5. Jiang, C. L. \& Xu, L. H. (1990). Improvement on cell disruption methods of actinomycetes in DNA preparation. Microbiology 17, 178-182.

6. Kelly, K. L. (1964). Inter-Society Color Council-National Bureau of Standards color-name charts illustrated with centroid colors published in US.

7. Lechevalier, M. P. \& Lechevalier, H. A. (1980). The chemotaxonomy of actinomycetes. In Actinomycete Taxonomy (Special Publication 6), pp. 22-291. Edited by A. Dietz \& D. W. Thayer. Arlington, VA : Society for Industrial Microbiology.

8. Locci, R. (1989). Streptomycetes and related genera. In Bergey's Manual of Systematic Bacteriology, vol. 4, pp. 2451-2508. Edited by S. T. Williams, M. E. Sharpe \& J. G. Holt. Baltimore: Williams \& Wilkins.

9. Maurer, H. R. (1971). Disc Electrophoresis and Related Techiques of Polyacrylamide Gel Electrophoresis, 2nd edn. Edited by W. G. Berlin. New York: de Gruyter.

10. Maidak, B. L., Larsen, N., McCaughey, M. J., Overbeek, R., Olsen, G. J., Fugel, K., Blandy, J. \& Woese, C. R. (1994). The Ribosomal Database Project. Nucleic Acids Res 22, 3485-3487.

11. Moreira, A. R., Philips, J. A. \& Humprey, A. E. (1981). Production of cellulases by Thermomonospora species. Biotechnol Bioeng 23, 1339-1347.

12. Mutsue, M., Majima, E. \& Ichishima, E. (1982). Specificity of thermophilic Streptomyces alkaline proteinase. Agric Biol Chem 46, 2485-2490.

13. Nonomura, H. \& Ohara, Y. (1969). Distribution of actinomycetes in soil. VI. A culture method effective for both preferential isolation and enumeration of Microbispora and Streptosporangium strains in soil. J Ferment Technol 47, 463-469.

14. Shirling, E. B. \& Gottlieb, D. (1966). Methods for characterization of Streptomyces species. Int $J$ Syst Bacteriol 16, 313-340.

15. Sunna, A., Moracci, M., Rossi, M. \& Antranikian, G. (1997). Glycosyl hydrolases from hyperthermophiles. Extremophiles 1, 2-13.

16. Tseng, M., Kudo, T. \& Seino, A. (1990). Identification of thermophilic actinomycetes isolated from mushroom compost in Taiwan. Bull Jpn Fed Cult Coll 6, 6-13.

17. Waldon, C. R. \& Eveleigh, D. E. (1986). Saccharification of cellulosics by Microbispora bispora. Appl Microbiol Biotechnol 24, 487-492.

18. Weeden, N. F. \& Wendel, J. F. (1986). Genetics of plant isozymes. In Isozymes in Plant Biology, pp. 46-72. Edited by D. E. Soltis \& P. S. Soltis. Portland, OR: Dioscorides Press.

19. Wendel, J. F. \& Weeden, N. F. (1989). Visualization and interpretation of plant isozymes. In Isozymes in Plant Biology, pp. 5-45. Edited by D. E. Soltis \& P. S. Soltis. Portland, OR: Dioscorides Press.

20. Zhou, H. (1978). Determination of the $\mathrm{G}+\mathrm{C}$ content of Corynebacterium pekinense and other bacterial species. Acta Microbiol Sin 18, 134-139. 
